\title{
Kastamonu Üniversitesi Orman Fakültesi'ni Markalaştırmaya Ve Marka Kimliğini Oluşturmaya Yönelik Bir Çalışma
}

\author{
Bahadır Çağrı BAYRAM ${ }^{1 *}$, Nadir ERSEN ${ }^{2}$, İlker AKYÜZ ${ }^{3}$ \\ ${ }^{1}$ Kastamonu Üniversitesi, Orman Fakültesi, Orman Endüstri Müh. Bölümü, Kastamonu \\ ${ }^{2}$ Artvin Çoruh Üniversitesi, Artvin Meslek Yüksek Okulu, Artvin \\ ${ }^{3}$ Karadeniz Teknik Üniversitesi, Orman Fakültesi, Orman Endüstri Müh. Bölümü, Trabzon
}

\section{Öz}

Bu çalışma kapsamında Kastamonu Üniversitesi (K. Ü.) Orman Fakültesinin markalaştırılması ve güçlü bir markanın sahip olacağı avantajlardan yararlanması hedeflenmektedir. Markalaşmaya giden yolda ilk adımlardan birisi marka kimliğinin oluşturulmasıdır. Dolayısıyla çalışmanın literatür kısmında markanın önemine değinilerek orman fakültesinin marka olması halinde potansiyel kazanımlarına vurgu yapılmıştır. Güçlü bir marka olmak için en başta etkili ve gerçekçi bir marka kimliğinin oluşturulması gerekmektedir. Bu bağlamda K. Ü. Orman Fakültesinin ülkemizdeki mevcut durumu paydaşlarla gerçekleştirilen görüşmelerle ve yapılan araştırmalar neticesinde ortaya konmuş olup, sonrasında fakülte bünyesindeki ilgililerle yapılan anket çalışmalarıyla zihinlerinde var olan marka algısı belirlenmiştir. Anket çalışmasında Aakerin marka kişiliği ölçeği kullanılmış olup, değişkenler kapsamında oluşturulan gruplar için t-testi, anova ve korelasyon analizi kullanılmış ve sonuçlar yorumlanmıştır. Neticesinde ise; K. Ü. Orman Fakültesinin alanında güçlü bir kurumsal marka ve etkili bir marka kimliğine sahip olması için yapılması gerekenler tespit edilmiş ve bu doğrultuda bir strateji önerilmiştir böylelikle markalaşmaya giden yolda ilk adımların atılmasına zemin hazırlanmıştır.

Anahtar Kelimeler: Markalaşma, Marka Kimliği, Kurumsal, Kastamonu Üniversitesi, Orman Fakültesi

\section{A Study on the Branding of Kastamonu University Faculty of Forestry and the Creation of Brand Identity}

\begin{abstract}
Within the scope of this research, Branding of Kastamonu University (K. U.) Faculty of Forestry and benefitting from the advantages of being a strong brand is aimed. One of the first steps on the road to branding is the creation of a brand identity. Therefore, in the literature review of the research, the importance of being a brand was emphasised and the possible benefits of being a branded faculty were underlined. For being a strong brand, firstly: an effective and realistic brand identity must be built. In this study, the current situation of K. U. Faculty of Forestry in our country was revealed with done stakeholder interviews and investigations. Afterwards, with the administered questionnaires; the brand awareness perception of stakeholders was determined. In the questionnaire, Aaker's brand personality scale was used; for the groups formed from the variables: t-test, anova and correlation analysis were used and the results were interpreted. As a result of these, a strategy was developed in order to have a strong corporate brand and an effective brand identity for K. U. Faculty of Forestry so that the first steps on the road to branding have been taken.
\end{abstract}

Keywords: Branding, Brand Identity, Corporate, Kastamonu University, Faculty of Forestry

\footnotetext{
*Sorumlu Yazar (Corresponding Author): 


\section{Giriş}

Literatürde marka ile ilgili oldukça çok tanımın yer aldığı görülmektedir. Fakat önde gelen tanımlar irdelendiğinde markayı tanımlamayan belli başlı ortak özellikler olduğu görülmektedir. Bunlar: markanın işletmeye sürdürülebilir bir avantaj sağladığı, ürünlerin veya hizmetlerin tanınmasına yardımcı olduğu, işletmeleri rakiplerinden farklılaştırdığı, isim, terim, işaret, simge, sembol, tasarım ya da bunların çeşitli birleşimlerinden oluştuğu ve ilgililerin karar verme sürecini basitleştirdiğidir (Aaker, 1991; Doyle ve Wong, 1997; Kotler, 1997; Keller, 1993).

Bugün marka işletmeler için çok önemli bir unsur olup, marka yaratmak ve ona değer katmak uzun ve meşakkatli bir planlama sürecine dayanmaktadır (Doyle, 2003). Marka kavramı işletmelerin sahip olduğu en değerli varlıklar arasında yer almaktadır çünkü günümüzde işletmeler sahip oldukları markalar aracılığı ile rakiplerinden ayırt edilir hale gelmişlerdir (Yüce, 2010). İşletmeler açısından güçlü bir markaya sahip olmak rekabet avantajı sağlamada ana unsurdur ve bu sayede markalar işletmelerin geleceklerini korurlar. Güçlü markalar işletme içerisinde amaçlara odaklanma, açıklık, kaliteli çalışanlarca tercih edilme, çalışanların iş tatmininin artması gibi bir takım avantajlar sağlar (Baldauf vd., 2003; Davis, 2002).

Marka kimliği marka ile ilgili olarak adı sıklıkla geçen kavramlardan birisidir. Marka kimliği markayı yönetenler veya işletme tarafindan oluşturulurken marka imajı daha çok ilgililer tarafından markaya atfedilir. Marka kimliği işletmelerin gerçekleriyle uyumlu olmalıdır ve genellikle ürün ya da hizmetin niteliklerine veya bunları edinmenin sağlayacağı faydalara yoğunlaşmalıdır (Kapferer, 1992; Aaker, 1995). Mantıksal olarak marka kimliği markanın tüm yönlerini kapsamakta ve parçalardan ziyade bütünle ilgilenmektedir. Dolayısıyla: konumlandırma, marka adı, logo, mesaj vb. marka yöneticileri tarafindan kontrol edilebilen unsurları içermektedir (Perry ve Wisnom, 2004). Teknik açıdan ise; marka kimliği markanın rekabetçi bir ortamda işletmenin gelişimini sürdürebilmesi ve büyümesi açısından önemlidir (Uztuğ, 2003). Marka kimliği rekabet halindeki diğer işletmelere marka tarafindan iletilen bir mesajdır (Doyle, 1998). Güçlü bir marka kimliği bir takım yararlar sağlar (Aaker, 1995; Çiftçi, 2006). Bunlar şu şekilde sıralanabilir:

-Markayı rakiplerinden farklı kılar.

-İlgililerin satın alma / tercih etme davranışına olumlu etki eder.

-İlgililere güven verir.

-Markaya karşı pozitif hisler oluşturur.

-Markanın geniş kitlelere ulaşmasına katkı sağlar.

-İlgililerde güçlü bir konumlandırma algısı oluşturur.

Bir işletmenin bir kimliğe ihtiyaç duymasının temel nedeni: içeride çalışanların kuruluş ile bütünleşmesini sağlamak dışarıda ise; diğer kuruluşlardan, rakiplerinden ayırt edilebilmek ve öne çıkmaktır (Okay, 2003). Kurumsal marka kimliği ilgililerin aklında çeşitli şekillerde oluşmaktadır. Ürünün / hizmetin nitelikleri, yararları, kurumun çevresiyle olan ilişkileri, değerleri, programları vb. ile zihinlerde şekillenmektedir (Beğendik, 2006 ).

Bu çalışmanın konusu, resmi bir kurum olan Kastamonu Üniversitesi Orman Fakültesinin alanında bir marka haline gelebilmesi ve bu maksatla; güçlü bir markayı oluşturacak temel öğelerden biri olan etkili bir marka kimliğine sahip olması için yapılması gerekenlerin tespitidir. Ülkemizde ki mevcut orman fakültelerin biri olan ve bu çalışmaya konu edilen fakültenin gerek öğrencilere gerekse ilgililere her anlamda daha iyi tanıtılıp pazarlanması maksadıyla; bu çalışmada "markalaşma" konu edilmiştir. Türkiye'de son yıllarda üniversite sayısındaki anormal artışa paralel olarak (Kaygın vd., 2015) orman fakültelerinin öğrenci sayılarının gitgide azaldığı ve kontenjanların da aynı doğrultuda düştüğü görülmektedir. Bu nedenle, kurumsal bir marka olarak kitlelere doğrudan etkili bir şekilde hitap edebilmek ve bu sayede tercih edilen, başarılı bir fakülte olabilmek bu çalışmanın kapsamı içerisindedir. Markalaşma çalışmalarına genellikle özel sektördeki kurumlar tarafindan son derece önem verilse de devlet kurumlarının da gerek yurt içi gerekse yurt dışı örneklerine bakıldığında rekabetin olduğu alanlarda öne çıkabilmek için markalaşma çabalarına giriştikleri görülmektedir. Bu çalışmanın ana amacı ise K.Ü. Orman Fakültesi'ni kurumsal bir marka haline getirerek gerek ülke gerekse dünya çapında ki diğer ilgili fakültelere karşı rekabet üstünlüğü kurabilmektir. Alanında marka olabilen bir kurum kendini çok daha kolay pazarlayabilmekte, dolayısıyla sahip olduğu kurumsal değeri daha da arttırabilmektedir. Çalışmanın ikincil amacı ise etkili bir marka kimliği oluşturarak yurt içi ve yurt dışında fakültenin bir marka olarak tanıtılması ve bu sayede mevcut fakülteler arasından sıyrılarak gerek Türk vatandaşı gerekse yabancı öğrenciler tarafindan tercih edilirliğinin arttırılmasıdır. Çalışmanın konusuna dair yapılan literatür taramasında da daha önce herhangi bir üniversitede/fakültede yapılan benzer bir çalışmaya rastlanmamış olup bu bağlamda da literatüre katkı sağlamak amaçlanmıştır. 


\section{Materyal ve Metot}

Bu çalışmada K.Ü. Orman Fakültesi araştırmaya konu edilmiştir. Dolayısıyla araştırma evreni olarak Orman Fakültesi belirlenirken, materyal olarak fakülteye dair verilerden ve paydaşların görüşlerinden yararlanılmıştır. Çalışma 3 aşamada gerçekleştirilmiştir. 1. aşamada K.Ü. Orman Fakültesinin kurumsal marka kimliğinin oluşturulması için paydaşlarla bilgi alışverişi gerçekleştirilmiştir: Kurum felsefesi, kurumsal davranış, kurumsal tasarım ve kurumsal iletişim unsurları ele alınarak yapılması gerekenler ortaya konmuştur. 2. aşamada ise mevcut öğrencilere ve personellere anket uygulanarak ilgililerin algıladıkları kimlik ve marka olmayı düzeyi tespit edilmiştir. 3. aşamada ise birinci ve ikinci aşamadan elde edilen bulgular harmanlanarak markalaşma yolunda yapılması gerekenler sıralanmış, güçlü bir marka kimliği oluşturmanın yol haritası sunulmuştur.

Çalışma yapıldığı tarihte fakültede mevcut aktif öğrenci sayısı 172, akademik personel sayısı 53 ve idari personel sayısı 6'dır. Bu durumda toplam paydaşların sayısı 231 olarak tespit edilmiştir. $\% 95$ güven düzeyi ve $\% 5$ hata oranı ile gerekli örnek büyüklügü̈ 144 olarak hesaplanırken fakültenin tümüne ulaşmak maksadıyla uygulanan anketlerden kullanılabilir olanların sayısı 164 olarak tespit edilmiştir.

Örnek hacmi belirlenirken ana kütlenin belli olduğu durumlarda kullanılan formülden faydalanılmıştır (Daniel, 1999):

$$
n=\frac{Z^{2} \cdot N \cdot Q Q}{N \cdot D^{2}+Z^{2} \cdot P Q Q}
$$

n: Örnek büyüklüğü

$\mathrm{N}$ : Populasyon büyüklüğü

Z: Güven katsayısı (\%95'lik güven katsayıs1 $=1.96)$

P: Ölçmek istediğimiz özelliğin ana kütlede bulunma ihtimali (Çalışmanın çok amaçlı olmasından dolayı bu oran $\% 50$ alınmıştır)

Q: 1-P

D: Kabul edilen örnekleme hatası (\%5 alınmıştır)

Kurumsal marka kişiliği boyutlarını ölçmede kullanılan ölçek Aaker'in (1997) Marka Kişiliği Ölçeğidir (Aaker, 1997). Ölçek için hazırlanan anket 2 kısımdan oluşmaktadır. 1. kısım demografik özellikleri irdeleyen sorulardan oluşurken 2. kısım algılanan marka kişiliği irdeleyen ve 5 boyut altında toplanan 40 maddeden oluşmaktadır. Boyutlar ve maddeler aşağıda sıralanmıştır:

1- Samimiyet (Tutarlı, Aile odakl1, Dürüst, İçten, Doğal, Erdemli, Orijinal, Eğlenceli, Duygusal, Dostça)

2- Heyecan (Cesur, Gündemi takip eden, Heyecan verici, Renkli, Karizmatik, Genç, Yaratıcı, Eşsiz, Güncel, Bağımsız, Modern)

3- Yetenek (Kendinden emin, Güvenilir, Çalışkan, Lider, Zeki, Teknik, Kurumsal, Başarılı, Güvenli)

4- Sofistike (Elit/Seçkin, Göz kamaştırıcı, iyi görünümlü, Çekici, Kadınsı, Şık)

5- Çetinlik (Sportif, Erkeksi, Güçlü, Çetin).

Araştırma verilerinin analizinde ise SPSS programı kullanılmıştır. Frekans tabloları, çapraz tablolar, t-testi, varyans analizi ve korelasyon analizi ise kullanılan istatistiksel analizlerdir.

\section{Bulgular ve Tartışma}

Bu çalışma kapsamında ankete katılanların cinsiyete göre dağılımları incelendiğinde çoğunluğun erkek olduğu görülmektedir. Aşağıda yer alan Tablo 1'de katılımcıların cinsiyete göre dağılımları hakkında detaylı bilgiler verilmektedir:

Tablo 1. Cinsiyete göre dağılım

\begin{tabular}{|l|l|l|l|l|l|}
\hline \multicolumn{2}{|c|}{} & Frekans & \% & Geçerli \% & Kümülatif \% \\
\hline \multirow{3}{*}{ Geçerli } & Erkek & 118 & 72.0 & 72.0 & 72.0 \\
\cline { 2 - 6 } & Kadın & 46 & 28.0 & 28.0 & 100.0 \\
\cline { 2 - 6 } & Total & 164 & 100.0 & 100.0 & \\
\hline
\end{tabular}


Katılımcıların yaşları irdelendiğinde elde edilen bulgular Tablo 2'de gösterilmiştir. Katılımcıların büyük çoğunluğu (\%50’si) 24 yaş ve altında yer almaktadır. Detaylı bilgi için Tablo 2 incelenebilir:

Tablo 2. Yaşa göre dağılım

\begin{tabular}{|l|l|l|l|l|l|}
\hline \multicolumn{2}{|c|}{} & Frekans & \% & Geçerli \% & Kümülatif \% \\
\hline \multirow{5}{*}{ Geçerli } & 24 ve küçük & 82 & 50.0 & 50.0 & 50.0 \\
\cline { 2 - 6 } & $25-29$ & 24 & 14.6 & 14.6 & 64.6 \\
\cline { 2 - 6 } & $30-34$ & 30 & 18.3 & 18.3 & 82.9 \\
\cline { 2 - 6 } & 35 ve üstü & 28 & 17.1 & 17.1 & 100.0 \\
\cline { 2 - 6 } & Total & 164 & 100.0 & 100.0 & \\
\hline
\end{tabular}

Eğitimle ilgili bulgular incelendiğinde katılımcıların çoğunluğunun $(\% 72,6)$ üniversite mezunu olduğu ya da eğitimi gördüğü belirlenmiştir. Tablo 3'de bu hususta daha detaylı bilgiler yer almaktadır:

Tablo 3. Eğitime göre dağılım

\begin{tabular}{|l|l|l|l|l|l|}
\hline \multicolumn{2}{|c|}{} & Frekans & \% & Geçerli \% & Kümülatif \% \\
\hline \multirow{4}{*}{ Geçerli } & Üniversite & 119 & 72.6 & 72.6 & 72.6 \\
\cline { 2 - 6 } & Yüksek lisans & 13 & 7.9 & 7.9 & 80.5 \\
\cline { 2 - 6 } & Doktora & 32 & 19.5 & 19.5 & 100.0 \\
\cline { 2 - 6 } & Total & 164 & 100.0 & 100.0 & \\
\hline
\end{tabular}

Katılımcıların medeni halleri irdelendiğinde çoğunluğun $(\% 63,4)$ bekâr olduğu görülmektedir. Detaylı bilgiler Tablo 4'te gösterilmektedir:

Tablo 4. Medeni hale göre dağılım

\begin{tabular}{|l|l|l|l|l|l|}
\hline \multicolumn{2}{|c|}{} & Frekans & \% & Geçerli \% & Kümülatif \% \\
\hline \multirow{3}{*}{ Geçerli } & Evli & 60 & 36.6 & 36.6 & 36.6 \\
\cline { 2 - 6 } & Bekar & 104 & 63.4 & 63.4 & 100.0 \\
\cline { 2 - 6 } & Total & 164 & 100.0 & 100.0 & \\
\hline
\end{tabular}

Çalışmaya katkı sağlayan bireylerin pozisyona göre dağılımları incelendiğinde elde edilen bulgular Tablo 5 'te verilmiştir:

Tablo 5. Pozisyona göre dağılım

\begin{tabular}{|c|c|c|c|c|c|}
\hline & & Frekans & $\%$ & Geçerli \% & Kümülatif \% \\
\hline \multirow{3}{*}{ Geçerli } & Öğrenci & 110 & 67.1 & 67.1 & 67.1 \\
\hline & $\begin{array}{l}\text { Personel } \\
\text { (akademik ve } \\
\text { idari) }\end{array}$ & 54 & 32.9 & 32.9 & 100.0 \\
\hline & Total & 164 & 100.0 & 100.0 & \\
\hline
\end{tabular}

Katılımcıların akademik unvanlarına göre dağılımları incelendiğinde çoğunluğun öğretim üyesi olduğu görülmüştür. Detaylar Tablo 6'da yer almaktadır:

Tablo 6. Unvana göre dağılım

\begin{tabular}{|l|l|l|l|l|l|}
\hline \multicolumn{2}{|c|}{} & Frekans & \% & Geçerli \% & Kümülatif \% \\
\hline \multirow{3}{*}{ Geçerli } & Arş. Gör. & 18 & 41.9 & 41.9 & 41.9 \\
\cline { 2 - 6 } & Öğr. Üyesi & 25 & 58.1 & 58.1 & 100.0 \\
\cline { 2 - 6 } & Total & 43 & 100.0 & 100.0 & \\
\hline
\end{tabular}

Anketi yanıtlayan fakülte mensuplarının ne kadar zamandır fakülteye dahil oldukları irdelendiğinde katılımcıların 24 tanesinin bu noktada bir görüş bildirmediği tespit edilmiş olup detaylı verilere Tablo 7'de yer verilmiştir: 
Tablo 7. Fakülte mensubu olmanın yıllara göre dağılımı

\begin{tabular}{|l|l|l|l|l|l|}
\hline \multicolumn{2}{|c|}{} & Frekans & \% & Geçerli \% & Kümülatif \% \\
\hline \multirow{5}{*}{ Geçerli } & 1 yıl & 21 & 12.8 & 15.0 & 15.0 \\
\cline { 2 - 6 } & 2 yıl & 18 & 11.0 & 12.9 & 27.9 \\
\cline { 2 - 6 } & 3 yll & 15 & 9.1 & 10.7 & 38.6 \\
\cline { 2 - 6 } & 4 yll & 26 & 15.9 & 18.6 & 57.1 \\
\cline { 2 - 6 } & 5 ve üstü & 60 & 86.6 & 12.9 & 100.0 \\
\cline { 2 - 6 } & Total & 140 & 14.6 & & \\
\hline Eksik & Sistem & 24 & 100.0 & & \\
\hline \multicolumn{1}{|c|}{ Total } & 164 & & & \\
\hline
\end{tabular}

Çalışmaya katılan bireylerin hangi bölümlere mensup olduğu analiz edildiğinde çoğunluğun orman mühendisliği bölümü içerisinde yer aldığı tespit edilmiştir. Fakültede resmi olarak yaban hayatı bölümü bulunmasına rağmen aktif olmadığı ve sadece 1 öğretim üyesi olduğundan, ilgili bölüm mesleki yakınlık göz önüne alınarak orman mühendisliği içerisinde değerlendirilmiştir. Ayrıca, idari personelin de bölümlere göre kadroları farklılaşmaktadır. Netice itibari ile toplamda 8 kişi görüş bildirmemeleri neticesinde herhangi bir tercihte bulunmamıştır. Bölümlerle ilgili detaylı verilere Tablo 8'den ulaşılabilir:

Tablo 8. Fakülte mensuplarının bölümlere göre dağılımı

\begin{tabular}{|c|c|c|c|c|c|}
\hline & & Frekans & $\%$ & Geçerli \% & Kümülatif \% \\
\hline \multirow{3}{*}{ Geçerli } & Orman Müh. & 126 & 76.8 & 80.8 & 80.8 \\
\hline & $\begin{array}{l}\text { Orman } \\
\text { Endüstri Müh. }\end{array}$ & 30 & 18.3 & 19.2 & 100.0 \\
\hline & Total & 156 & 95.1 & 100.0 & \\
\hline Eksik & $\begin{array}{l}\text { Görüş } \\
\text { Bildirmeyen }\end{array}$ & 8 & 4.9 & & \\
\hline \multicolumn{2}{|l|}{ Total } & 164 & 100.0 & & \\
\hline
\end{tabular}

$\mathrm{Bu}$ araştırma kapsamında görüş bildiren bireylerin gelir seviyeleri irdelendiğinde 1 kişinin görüş bildirmediği belirlenmiş olup, çoğunluğun $(\% 30,1)$ 2001-3500€ gelir seviyesi aralığında olduğu tespit edilmiştir. Gelir seviyesiyle ilgili detaylar Tablo 9'da gösterilmiştir:

Tablo 9. Gelire göre dağ 1 lım

\begin{tabular}{|c|c|c|c|c|c|}
\hline & & Frekans & $\%$ & Geçerli \% & Kümülatif \% \\
\hline \multirow{7}{*}{ Geçerli } & 2000 ve alt1 & 30 & 18.3 & 18.4 & 18.4 \\
\hline & $2001-3500$ & 49 & 29.9 & 30.1 & 48.5 \\
\hline & $3501-5000$ & 27 & 16.5 & 16.6 & 65.0 \\
\hline & $5001-6500$ & 17 & 10.4 & 10.4 & 75.5 \\
\hline & $6501-8000$ & 17 & 10.4 & 10.4 & 85.9 \\
\hline & 8001 ve üstü & 23 & 14.0 & 14.1 & 100.0 \\
\hline & Total & 163 & 99.4 & 100.0 & \\
\hline Eksik & Sistem & 1 & .6 & & \\
\hline \multicolumn{2}{|l|}{ Total } & 164 & 100.0 & & \\
\hline
\end{tabular}

\subsection{Analizlere Ait Bulgular}

Araştırma verilerinin analizinde "IBM SPSS Statistics Version 23" programı kullanılmıştır. Öncelikle güvenilirlik düzeyini test etmek için cronbach alpha katsayısı test edilmiştir. Çalışmanın cronbach alpha iç tutarlılık katsayısı 0.979 ile çalışmanın çok yüksek güvenilirlik düzeyine sahip olduğunu göstermiştir Marka kişiliği ölçeği irdelendiğinde tespit edilen genel durum Tablo 10' da gösterilmiştir: 
Tablo 10. Marka kişilik ölçeği genel değerlendirme sonuçları

\begin{tabular}{|l|l|l|l|}
\hline Boyut & Ortalama & Stand. Sap. & Cronbach's Alfa \\
\hline Samimiyet & 3.271 & 1.21 & 0.936 \\
\hline Heyecan & 3.06 & 1.31 & 0.941 \\
\hline Yetenek & 3.385 & 1.06 & 0.952 \\
\hline Sofistike & 2.829 & 1.207 & 0.893 \\
\hline Çetinlik & 3.068 & 1.251 & 0.799 \\
\hline Genel & $\mathbf{3 . 1 5 2 6}$ & $\mathbf{1 . 0 9 8}$ & $\mathbf{0 . 9 7 9}$ \\
\hline
\end{tabular}

Tablo 10'dan da görüleceği üzere: samimiyet ve yetenek boyutları nispeten genel ortalamanın üstünde yer alırken heyecan, sofistike ve çetinlik boyutları genel ortalamanın altında kalmaktadır. Boyutların sıralaması ise şu şekilde olmuştur: Yetenek 1. sırada yer alırken Samimiyet 2. sırada yer almaktadır. 3. sırada heyecan ve çetinlik yer alırken 4. sırada sofistike olmak yer almaktadır.

Daha açıklayıcı olabilmek adına; boyutların altında yer alan yargıların genel durumu incelendiğinde elde edilen bulgular Tablo 11'deki gibi olmuştur:

Tablo 11. Yargıların genel değerlendirme sonuçları

\begin{tabular}{|c|c|c|c|c|}
\hline & Ortalama & Stand. Sap. & Çarpıklık & Basıklık \\
\hline Gerçekçi & 3.4417 & 1.03099 & -0.594 & -0.061 \\
\hline Aile odaklı & 3.2393 & 1.05897 & -0.272 & -0.624 \\
\hline dürüst & 3.3519 & 1.07756 & -0.409 & -0.531 \\
\hline İçten & 3.3865 & 1.04424 & -0.567 & -0.305 \\
\hline Doğal & 3.5 & 1.11595 & -0.543 & -0.454 \\
\hline Erdemli & 3.3902 & 1.03623 & -0.506 & -0.087 \\
\hline Orijinal & 3.3988 & 1.13605 & -0.373 & -0.645 \\
\hline Eğlenceli & 2.8642 & 1.2536 & -0.104 & -1.098 \\
\hline Duygusal & 2.8951 & 1.129 & -0.001 & -0.766 \\
\hline Dostça & 3.3457 & 1.08245 & -0.607 & -0.241 \\
\hline Cesur & 3.1304 & 1.17861 & -0.187 & -0.799 \\
\hline Gündemi takip eden & 3.4037 & 1.13125 & -0.479 & -0.539 \\
\hline Heyecan verici & 2.7988 & 1.1888 & -0.002 & -0.875 \\
\hline Renkli & 2.9018 & 1.19265 & -0.052 & -0.976 \\
\hline Karizmatik & 2.8466 & 1.16313 & -0.125 & -0.856 \\
\hline Genç & 3.4286 & 1.1764 & -0.631 & -0.442 \\
\hline Yaratic1 & 2.9877 & 1.15997 & -0.024 & -0.843 \\
\hline Eşsiz/Tek & 2.5963 & 1.20612 & 0.256 & -0.854 \\
\hline Çağdaş & 3.2012 & 1.06926 & -0.411 & -0.385 \\
\hline Bağımsız & 3.2188 & 1.12531 & -0.361 & -0.64 \\
\hline Modern & 3.1801 & 1.10617 & -0.279 & -0.657 \\
\hline Kendinden emin & 3.3704 & 0.93176 & -0.432 & 0.075 \\
\hline Güvenilir & 3.3913 & 1.01964 & -0.382 & -0.449 \\
\hline Çalışkan & 3.4815 & 0.96022 & -0.714 & 0.283 \\
\hline Lider & 3.2025 & 1.04916 & -0.285 & -0.31 \\
\hline Zeki & 3.3497 & 1.04547 & -0.349 & -0.301 \\
\hline Teknik & 3.3129 & 1.0454 & -0.46 & -0.22 \\
\hline Kurumsal & 3.411 & 1.08144 & -0.612 & -0.265 \\
\hline Başarılı & 3.4753 & 1.02273 & -0.673 & 0.091 \\
\hline Güvenli & 3.4207 & 1.05659 & -0.468 & -0.267 \\
\hline Elit/Seçkin & 3.037 & 1.13054 & -0.256 & -0.653 \\
\hline Göz kamaştırıcı & 2.689 & 1.11085 & -0.011 & -0.85 \\
\hline İyi görünümlü & 3.1646 & 1.06982 & -0.456 & -0.472 \\
\hline Çekici & 2.8098 & 1.09743 & 0.045 & -0.735 \\
\hline Kadinst & 2.3841 & 1.10437 & 0.243 & -0.751 \\
\hline Ş1k & 2.8659 & 1.05391 & 0.049 & -0.511 \\
\hline Sportif & 2.9259 & 1.16126 & -0.167 & -0.779 \\
\hline Erkeksi & 2.9024 & 1.13624 & -0.289 & -0.79 \\
\hline Güçlü & 3.184 & 1.07863 & -0.464 & -0.349 \\
\hline Çetin & 3.2209 & 1.10568 & -0.337 & -0.399 \\
\hline
\end{tabular}


Açık gri renkte gösterilen yargılar her boyutta ki en yüksek puana sahip olan yargıyı ifade etmektedir. Bu durumda samimiyet boyutu içerisinde yer alan ve en yüksek puana sahip olan yarg1 "doğal" iken, heyecan boyutunda yer alan en yüksek puana sahip yargı "genç" olmuştur. Yetenek boyutundaki en yüksek puana sahip olan yargı "zeki" iken, sofistike boyutunda yer alan en yüksek puana sahip yarg1 "iyi görünümlü" olmuştur. Çetinlik boyutunda ise en yüksek puana sahip yargı "çetin" olmuştur. Buradaki bulguları özetleyecek olursak: "Doğal" tüm yargılar içerisinde en yüksek puana sahiptir. Onu ikinci sırada yer alan "genç" yargısı izlerken 3. sırada "zeki”" 4. sırada "çetin" ve 5. sırada "iyi görünümlü olmak" izlemektedir. "Kadınsı" ifadesi ise bütün yargılar arasında en düşük puana sahiptir.

Bu sonuçları daha iyi irdelemek adına bir takım detaylı analizler de yapılmışıtır.

Normallik testi için çarpıklık ve basıklık değerlerine bakılmıştı. Çarpıklık ve basıklık değerleriyle verilerin normal dağılldığı gözlenmiştir. Yargılar incelendiğinde çarpıklık değeri -0.714 ile 0.256 arasında basıklık değeri ise -1.098 ile 0,283 arasında değiştiği gözlenmiştir. Basıklık ve çarpıklık değerleri -1.5 ile +1.5 olduğu zaman normal dağılım olduğu kabul edilmektedir (Tabachnick and Fidell, 2013). Değişkenler kapsamında oluşturulan gruplar için t-testi, anova ve korelasyon analizi sonuçları yorumlanmıştır.

Öncelikli olarak yargılar ile demografik özelliklerin ortalamalar açısından fark gösterip göstermediği test edilmiştir. İstatistiksel olarak anlamlı bir farklılığa sahip örneklem grupları Tablo 12'de gösterilmiştir.

Tablo 12. Yargılar ve demografik özelliklerin T-testi ve Anova analizi sonuçları

\begin{tabular}{|c|c|c|c|c|c|c|c|}
\hline Yargi & & \multicolumn{3}{|l|}{ Kadın } & p değeri \\
\hline Çalışkan & \multirow{2}{*}{\multicolumn{3}{|c|}{3.3983}} & \multicolumn{3}{|l|}{3.7045} & 0.042 \\
\hline Zeki & & & 3.2308 & \multicolumn{3}{|l|}{3.6522} & 0.008 \\
\hline Teknik & \multicolumn{3}{|l|}{3.188} & \multicolumn{3}{|l|}{3.6304} & 0.005 \\
\hline Kurumsal & \multicolumn{3}{|l|}{3.2479} & \multicolumn{3}{|l|}{3.8261} & 0.000 \\
\hline Başarılı & \multicolumn{3}{|l|}{3.3504} & \multicolumn{3}{|l|}{3.8} & 0.004 \\
\hline Kadıns1 & \multicolumn{3}{|l|}{2.2712} & \multicolumn{3}{|l|}{2.6739} & 0.036 \\
\hline Yargı & \multicolumn{3}{|c|}{ Arş. Gör. } & \multicolumn{3}{|l|}{ Öğr. Üyesi } & p değeri \\
\hline Erkeksi & \multicolumn{3}{|c|}{3.5556} & \multicolumn{3}{|l|}{2.8} & 0.021 \\
\hline Yargı & \multicolumn{3}{|l|}{ Öğrenci } & \multicolumn{3}{|l|}{ Personel } & p değeri \\
\hline Gündemi takip eden & \multicolumn{3}{|l|}{3.2336} & \multicolumn{3}{|l|}{3.7407} & 0.004 \\
\hline Genç & \multicolumn{3}{|l|}{3.2091} & \multicolumn{3}{|l|}{3.902} & 0.000 \\
\hline Çalışkan & \multicolumn{3}{|l|}{3.3578} & \multicolumn{3}{|l|}{3.7358} & 0.008 \\
\hline Yargı & \multicolumn{2}{|c|}{24 ve küçük } & $25-29$ & \multicolumn{3}{|c|}{35 ve üstü } & p değeri \\
\hline Renkli & \multirow{2}{*}{\multicolumn{2}{|c|}{2.716}} & 2.792 & \multirow{2}{*}{$\begin{array}{l}2.967 \\
3.862\end{array}$} & \multicolumn{2}{|c|}{3.4643} & 0.035 \\
\hline Genç & & & 3.292 & & 3.8929 & & 0.004 \\
\hline Yaratic1 & 2.963 & & 2.75 & 2.733 & 3.5357 & & 0.031 \\
\hline Lider & 3.2346 & & 2.875 & 2.967 & 3.6429 & & $\mathbf{0 . 0 3}$ \\
\hline Başarıl1 & 3.425 & & 3.208 & 3.367 & 3.9643 & & 0.034 \\
\hline Elit/Seçkin & 3.0854 & & 2.696 & 2.759 & 3.4643 & & 0.044 \\
\hline Yargi & Ünivers & & & Yüksek lisans & Dok & & p değeri \\
\hline Gündemi takip eden & 3.25 & & & 3.7692 & 3.81 & & 0.021 \\
\hline Genç & 3.2069 & & & 3.9231 & 4.03 & & 0.000 \\
\hline Yargi & $\begin{array}{l}2000 \\
\text { TL ve } \\
\text { altı }\end{array}$ & $\begin{array}{l}\text { 2001- } \\
\text { 3500 } \\
\text { TL }\end{array}$ & $\begin{array}{l}3501- \\
5000 \\
\text { TL }\end{array}$ & $\begin{array}{l}\mathbf{5 0 0 1 -} \\
\mathbf{6 5 0 0} \\
\text { TL } \\
\end{array}$ & $\begin{array}{l}\text { 6501- } \\
8000 \\
\text { TL }\end{array}$ & $\begin{array}{l}8001 \\
\text { TL ve } \\
\text { üstü }\end{array}$ & p değeri \\
\hline Gündemi takip eden & 3.3571 & 3.1042 & 3.3704 & 3.3529 & 4.0588 & 3.7391 & 0.044 \\
\hline Renkli & 2.6667 & 2.4792 & 3.0741 & 3.2353 & 3.5294 & 3.2174 & 0.007 \\
\hline Genç & 2.8966 & 3.1489 & 3.4815 & 3.5294 & 4 & 4.1739 & 0.000 \\
\hline Güvenli & 3.1667 & 3.2653 & 3.5556 & 3.1176 & 3.7647 & 3.913 & 0.042 \\
\hline
\end{tabular}


Tablo 12'ye göre ilgili yargılar cinsiyet, akademik unvan, fakültedeki pozisyon, yaş, eğitim düzeyi ve gelir düzeyi kriterlerine göre ortamalar açısından istatistiksel anlamlı farklılıklar göstermektedir $(\mathrm{p}<0.05)$. Tablodaki bulgular örnek olarak şu şekilde yorumlanabilir: Yaratıcı yargısına verilen cevapların ortalaması yaş değişkenine göre değişiklik göstermektedir. Bu yargıya en yüksek puanı 35 yaş ve üstündeki bireyler verirken en düşük puanı 30-34 yaş aralığındakiler vermiştir.

Marka kişiliğini oluşturan boyutlar ve demografik özelliklerin ortalamalar açısından fark gösterip göstermediği test edildiğinde bazı kriterlerin anlamlı farklılıklar gösterirken bir kısmının göstermediği tespit edilmiştir. İstatistiksel olarak anlamlı farklılık gösteren kriterler Tablo 13'te verilmiştir:

Tablo 13. Boyutlar ve demografik özelliklerin T-testi ve Anova analizi sonuçları

\begin{tabular}{|l|l|l|l|}
\hline Boyut & Erkek & Kadın & p değeri \\
\hline Yetenek & 3.2847 & 3.6265 & $\mathbf{0 . 0 0 8}$ \\
\hline Boyut & Evli & Bekar & p değeri \\
\hline Heyecan & 3.2761 & 2.9377 & $\mathbf{0 . 0 2 4}$ \\
\hline Yetenek & 3.5905 & 3.2594 & $\mathbf{0 . 0 1 7}$ \\
\hline
\end{tabular}

Tablo 13 incelendiğinde ilgili boyutlar demografik özelliklerden sadece cinsiyet ve medeni hal kriterleri ile ortamalar açısından istatistiksel anlamlı farkl1lıklar göstermiştir $(\mathrm{p}<0.05)$. Boyut bazında diğer kriterlerin herhangi bir farklılık gösterdiği bu çalışma kapsamında tespit edilmemiştir.

Marka kişiliği ölçeğinde yer alan boyutların neredeyse tümünün birbiri ile pozitif ve yüksek korelasyon gösterdiği tespit edilmiştir. Analize ait veriler Tablo 14'te gösterilmiştir:

Tablo 14. Boyutların Korelasyon analizi sonuçları

\begin{tabular}{|l|l|l|l|l|l|}
\hline & Samimiyet & Heyecan & Yetenek & Sofistike & Çetinlik \\
\hline Samimiyet & 1 & $0,82^{* *}$ & $0,836^{* *}$ & $0,724^{* *}$ & $0,652^{* *}$ \\
\hline Heyecan & $0,82^{* *}$ & 1 & $0,871^{* *}$ & $0,829^{* *}$ & $0,765^{* *}$ \\
\hline Yetenek & $0,836^{* *}$ & $0,871^{* *}$ & 1 & $0,758^{* *}$ & $0,701^{* *}$ \\
\hline Sofistike & $0,724^{* *}$ & $0,829^{* *}$ & $0,758^{* *}$ & 1 & $0,738^{* *}$ \\
\hline Çetinlik & $0,652^{* *}$ & $0,765^{* *}$ & $0,701^{* *}$ & $0,738^{* *}$ & 1 \\
\hline ** Korelasyon & 0.01 anlam düzeyinde anlamlidır. \\
\hline
\end{tabular}

\section{Sonuç ve Öneriler}

Öncelikli olarak demografik bulgulara dair sonuçlardan bazılarına değinmek gerekmektedir; Çalışmaya katılanların \%72,6'sı üniversite (lisans), \%7,9'u yüksek lisans ve \%19,5'i doktora öğrencisi veya mezunudur. Söz konusu kişilerin fakültedeki pozisyonları incelendiğinde \%67,1'inin öğrenci olduğu ve \%32,9'unun da akademik veya idari personel olduğu görülmektedir. Fakültedeki akademik personelin $\% 41,9$ 'unun lisans üstü eğitim gördüğü ve \%58, l'inin de doktor unvanına sahip olduğu ve idari personelin de bir kısmının lisans mezunu olduğu veya aynı zamanda öğrenci olduğu göz önüne alındığında veriler arasında bir tutarsızlık bulunmadığı görülmektedir.

Öte yandan katılımcıların \%67,1'i öğrenci iken fakülte mensuplarının gelir düzeyinin ortalama olarak 4000€ civarında olduğu görülmektedir. Bunun sebebi katılımcıların aldığı bursalar, part-time çalışmaları ve bir kısmının farklı kamu kurumlarında çalışmalarından kaynaklandığı gibi; çoğunluğunun gelirle ilgili soruda ailelerinin gelir düzeylerini göze alarak cevap verdikleri tespit edilmiştir.

Son olarak, fakülte mensubu olma süresi incelendiğinde katılımcıların \%15'inin (24) anonimliklerini korumak adına görüş bildirmedikleri tespit edilmiştir.

Analizler neticesinde elde edilen bulgular incelendiğinde açıkça görülüyor ki K.Ü. Orman Fakültesine dair herhangi bir marka kişiliği algısı çalışmanın gerçekleştiği tarih itibari ile mensuplarının zihninde oluşmamıştır. Hemen hemen bütün kriterlerde kararsızlık hâkim olmakla beraber sadece "sofistike olmak" seçeneğine paydaşların katılmadığı tespit edilmiş̧ir.

Bu nedenle öncelikli olarak fakültenin bir marka kişiliği oluşturma çalışması yapması gerekmektedir. Burada olması gereken hareket noktası ise nispeten daha yüksek puana sahip olan "yetenek" ve "samimiyet" boyutlarıdır. Özellikle bu boyutları ön plana çıkaracak algı çalışmaları yapılmalıdır. Önerilen bu çalışmalar 
pazarlama ve tanıtım faaliyetleri olarak ilk etapta belirlenebilir. Paydaşlara K.Ü. Orman Fakültesinin yetenekli bireylerden oluşan samimi bir ortama sahip bir organizasyon olduğu hissettirilmelidir. Bu noktada özellikle sosyal medya, yazılı ve görsel basının etkin bir şekilde kullanılması önerilmektedir. Marka kişiliğini bu boyutlar üzerinden şekillendirme aşamasında da: mevcut ölçekte ilgili boyutlarda en yüksek puana sahip olan "doğallık", "genç olmak", "zeki olmak", "iyi görünüme sahip olmak" ve "çetin olmak" yargıları marka imajı oluşturulurken özellikle önemsenmeli ve kullanılmalıdır.

Benimsenecek bu tutum diğer zayıf yönlere odaklanarak zaman kaybetmenin önüne geçecek ve fakültede kendi mevcut yapısından kaynaklı sahip olduğu güçlü yönlerin daha da gelişmesine neden olacaktır.

Kısaca özetlemek gerekirse K.Ü. Orman Fakültesinin yetenekli ve samimi bir kişiliği olduğunun ve bu kişilik yapısının da sahip olduğu doğallığı, gençliği, zekası, iyi görüntüsü ve mücadeleci ortamından kaynaklandığını bireylere ifade etmek ve bu şekilde kabullendirmek gerekmektedir. Böylece fakülte, bireylerin zihninde bahsedilen özelliklere sahip olarak addedilerek konumlanacak ve markalaşma yolunda önemli bir adım atılabilecektir.

Bu çalışma kapsamında K.Ü. Orman Fakültesinin kurumsal bir marka olabilmesi için öncelikle bir marka kişiliği geliştirmesi gerektiği ve bu kişilik için nasıl bir imaj oluşturması gerektiği tespit edilmiş ve öncelikli hedef olarak önerilmiştir.

\section{Teşekkür}

Bu çalışma Kastamonu Üniversitesi, Bilimsel Araştırma Projeleri Yönetimi Koordinatörlüğü’nün KÜBAP01/2017-70 Nolu projesi kapsamında desteklenmiştir.

\section{Kaynaklar}

1. Aaker J.L., 1997. "Dimensions Of Brand Personality", Journal of Marketing Research, Vol. 34, 347-356

2. Aaker, D., A., 1991. Managing Brand Equity: Capitalizing on the Value of a Brand Name, The Free Press, Macmillan Inc., New York, USA.

3. Aaker, J.L., 1995. Conceptualizing and Measuring Brand Personality: A Brand Personality Scale, Standford University, December.

4. Baldauf, A., Cravens, K., S. and Binder, G., 2003. Performance Consequences Of Brand Equity Management: Evidence From Organizations In The Value Chain, Journal of Product \& Brand Management, $12,4,220-236$.

5. Beğendik, B., 2006. Perakendecilikte Kurumsal Marka Kimliği ve Saha Çalışması, Yayınlanmamış Yüksek Lisans Tezi, Marmara Üniversitesi, Sosyal Bilimler Enstitüsü, İstanbul.

6. Çiftçi, S., 2006. Marka ve Marka Sadakati: Üniversite Öğrencilerinin Kot Pantolon Marka Tercihleri ve Marka Sadakati ile İlgili Bir Araştırma, Yayınlanmamış Yüksek Lisans Tezi, Abant İzzet Baysal Üniversitesi, Sosyal Bilimler Enstitüsü, Bolu.

7. Daniel, W.W., 1999. Biostatistics A Foundation for Analysis in the Health Sciences, Sixth. ed. John Wiley \& Sons, Inc.

8. Davis, S., 2002. Brand Asset Management 2: How Businesses Can Profit From The Power Of Brand, Journal of Consumer Marketing, 19, 4, 351 - 358.

9. Doyle, P. and Wong, V., 1997. An Exploration of Branding in Industrial Markets, Industrial Marketing Management, 26, 5, 433-446.

10. Doyle, P., 1998. Marketing, Prentice Hall, London.

11.Doyle, P., 2003. Değer Temelli Pazarlama: Şirketinizi Büyütmek ve Hissedar Değeri Yaratmak İçin Pazarlama Stratejileri, Çev. Gülfidan Barış, Kapital Medya Hizmetleri A.Ş., İstanbul.

12. Kapferer, J., N., 1992. Strategic Brand Management: New Approaches to Creating and Evaluating Brand Equity, Maxwell Macmillian, Inc., New York.

13. Kaygın, B. Kurt, R. Ve İmren, E., 2015. Bartın Üniversitesi Orman Endüstri Mühendisliği Mezunlarının İstihdam Durumu Üzerine Bir Araştırma, Bartın Orman Fakültesi Dergisi, 17, 25-26, 54-61.

14. Keller, K., L., 1993. Conceptualizing, Measuring and Managing Customer Based Brand Equity, Journal of Marketing, 57, 1-22.

15. Kotler, P., 1997. Marketing Management: Analysis, Planning, Implementation, and Control, 9th Edition, Prentice-Hall International Inc., New Jersey, USA.

16. Okay, A., 2003. Kurum Kimliği, İstanbul: Mediacat Kitapları.

17. Perry, A. ve Wisnom III, D., 2004. Markanın DNA‘sı, Çev: Zeynep Yılmaz, MediaCat Yayınları, İstanbul. 
18. Tabachnick, B. G. And Fidell, L. S., 2013. Using multivariate statistics. Boston, Pearson.

19. Uztŭg, F., 2003. Markan Kadar Konuş: Marka İletişim Stratejileri, MediaCat Yayınları, İstanbul.

20. Yüce, A., 2010. Bütünleyici Bir Model İle Marka Değeri Ölçümü, Doktora Tezi, Atatürk Üniversitesi, Sosyal Bilimler Enstitüsü, Erzurum. 